\title{
SISTEM INFORMASI MANAJEMEN RUANGAN PROGRAM STUDI TEKNIK INFORMATIKA MENGGUNAKAN FRAMEWORK LARAVEL
}

\author{
(Room Management Information System In Departement Informatics Engineering \\ Using Laravel Framework)
}

\author{
Fuad Fadlila Surenggana $^{[1]}$, Fitri Bimantoro ${ }^{[1]}$, Rival biasrori ${ }^{[1]}$ \\ ${ }^{[1]}$ Dept Informatics Engineering, Mataram University \\ J1. Majapahit 62, Mataram, Lombok NTB, INDONESIA \\ Email: fuad.surenggana@gmail.com, [bimo, rival]@unram.ac.id
}

\begin{abstract}
Abstrak
Kepentingan untuk mengatur suatu hal dalam meningkatkan pekerjaan agar lebih efektif dan efisien selalu ingin dicapai. Penggunaan teknologi informasi sebagai salah satu solusinya, dengan memanfaatkan sistem informasi hasil dari perkembangan teknologi pada perguruan tinggi yang akan diterapkan di perguruan tinggi pula. Ruangan menjadi salah satu instrument penting dalam kegiatan di perguruan tinggi Mengatur suatu ruangan untuk digunakan tidaklah mudah terutama jika perlu melakukan pekerjaan-pekerjaan lain, dimana membuat pendataan menjadi masalah tersendiri. Maka pada pengabdian masyarakat ini dibuatlah sistem informasi manajemen ruangan pada program studi Teknik informatika dengan menggunakan framework Laravel untuk mengatasi permasalan pendataan yang terjadi. Dilakukan pengujian terhadap sistem dengan menggunakan Black Box Testing yaitu melakukan test pada tiap-tiap bagian komponen maupun fitur yang terdapat pada sistem informasi ini dan Mean Opinion Score (MOS) dengan memberikan kuesioner kepada beberapa responden mengenai sistem informasi yang telah dibuat, responden memberikan nilai yang sifatnya subjektif mengenai kegunaannya, visualisasi sistem, keinformatifan sistem, kebutuhan sistem dan kemudahan pekerjaan. Dengan didapatkannya nilai dari responden, nilai-nilai tersebut dapat diproses sehingga didapatkan nilai 69.6 dari maksimal nilai 100 untuk sistem yang telah dibuat. Nilai MOS kemudian di konversikan ke dalam Absolute Category Rating (ACR) dengan nilai 3.48 yang menunjukkan Sistem Informasi Manajemen Ruangan mendapat hasil yang cukup.
\end{abstract}

Keywords: Sistem Informasi, Ruangan, Laravel, Black Box Testing, Mean Opinion Score

\section{Pendahuluan}

Ruangan atau kelas diperlukan suatu institusi Pendidikan Tinggi untuk kegiatan perkulian yang terjadwal sehari-hari. Ruangan juga dapat digunakan untuk kegiatan lain seperti kuliah pengganti, seminar-seminar maupun kegiatan akademis lainnya. Program Studi Informatika Universitas Mataram merupakan salah satu institusi Pendidikan Tinggi yang memiliki beberapa ruangan untuk dikelola dalam memenuhi kegiatan perkuliahan.

Dosen maupun mahasiswa dapat meminjam ruangan pada bagian administrasi prodi langsung, sehingga proses kegiatan akademik maupun non-akademik dapat terus berjalan. Namun demikian, karena data ruangan-ruangan yang telah disimpan masih secara manual, yang dapat menimbulkan kesalahan seperti lupa jadwal kegiatan di suatu ruangan maupun terbenturnya jadwal antar kegiatan sehingga menyebabkan pelayanan menjadi tidak efisien menimbulkan proses birokrasi menjadi lambat.

Perkembangan di dunia pendidikan terutama perguruan tinggi seiring dengan laju perkembangan teknologi informasi yang beraneka ragam. Penggunaan teknologi informasi terutama sistem informasi berperan penting dan dapat menjadi solusi untuk mengatasi pengolahan data agar kegiatan ini dilakukan cepat, akurat, dan informatif [1]. Perguruan tinggi harusnya dapat dijadikan asal muasal dan panutan terciptanya suatu produk inovasi. Karena pada perguruan tinggi terdapat banyak sumber daya manusia yang dapat melahirkan ide-ide untuk mengatasi permasalah di sekitar dengan cara yang efektif.

Untuk mengatasi permasalahan tersebut maka pada pengabdian masyarakat ini dibuat "Sistem Informasi Manajemen Ruangan Program Studi Teknik Informatika menggunakan Framework Laravel”. Dengan adanya sistem ini diharapkan dapat membantu staf prodi dalam memberikan pelayanan untuk mengatur manajemen ruangan agar pekerjaan menjadi lebih efektif dan efisien. Tujuan dari pembuatan sistem ini adalah untuk merancang dan membangun sebuah Sistem Informasi Manajemen Ruangan berbasis web yang dapat digunakan untuk membuat pelayanan Program Studi Teknik Informatika menjadi lebih efektif dan efisien. Adapun manfaat dari pembuatan sistem ini adalah dapat memudahkan dosen dan mahasiswa dalam proses peminjaman ruangan untuk menjalankan proses akademik maupun non-akademik, memudahkan staf dalam pengerjaan administrasi peminjaman ruangan, 
mengatur ruangan, dan mengingatkan jadwal peminjaman ruangan, dan dapat memudahkan pihak Program Studi dalam mengelola ruangan yang ada dan meningkatkan efektifitas dan efisiensi dalam proses pelayanan Program Studi Teknik Informatika.

\section{Tinjauan Pustaka}

\subsection{Referensi Terkait}

Sebagai bahan referensi untuk membantu dalam pembuatan sistem informasi manajemen ruangan ini, maka terdapat beberapa jurnal yang terkait dengan pembuatan sistem informasiini, antara lain:

1. Sistem Informasi Manajemen Ruang (SIMERU) Kelas (Studi Kasus: FKTI Universitas Mulawarman) oleh Dyna Marisa dkk., pada tahun 2018, sistem digunakan membantu admin dalam proses penjadwalan ruang perkuliahan sehingga meminimalisir jadwal yang berbenturan maupun memudahkan untuk mengatur jdawal ruang kelas pengganti dengan model reservasi ruangan disertai dengan waktu dan tempat [2].

2. Selamat Tinggal Bentrok! Efisiensi Pengelolaan Jadwal Kuliah dengan SIM- DRaW (Sistem Informasi Manajemen Dosen, Ruang, dan Waktu) oleh Nugraha dan Nugraha pada tahun 2018 mengenai Sistem Informasi Manajemen Dosen, Ruang, dan Waktu, sistem digunakan untuk membantu memenuhi kebutuhan dan mengatasi permasalahan pengelolaan jadwal kuliah sehingga mampu menghindari terjadinya jadwal yang berbenturan sejak awal jadwal kuliah dibuat [3].

\subsection{Sistem Informasi}

Sistem Informasi adalah suatu sistem di dalam suatu organisasi yang merupakan kombinasi dari orang-orang, fasilitas, teknologi, media, prosedur-prosedur dan pengendalian yang ditujukan untuk mendapatkan jalur komunikasi yang penting, memproses tipe transaksi rutin tertentu, memberi sinyal menajemen terhadap kejadiankejadian internal dan eksternal yang penting dan menyediakan suatu dasar informasi untuk pengambilan keputusan yang baik [4].

Sistem Informasi berpengaruh pada aktifitas di perguruan tinggi dalam aktifitas akademiknya [1]. Pemanfaatan hasil penelitian terkait sistem informasi untuk instansi atau masyarakat banyak digunakan yaitu Sistem Informasi Manajemen Ruangan (SIMERU) [3] dan Sistem Informasi Manajemen Dosen, Ruang, dan Waktu Kuliah untuk pengelolaan jadwal kuliah [4]. .

\subsection{Sistem Informasi Manajemen}

Sistem Informasi Manajemen adalah sebagai suatu sistem berbasis komputer yang menyediakan informasi bagi beberapa pemakai dengan kebutuhan serupa. Output informasi digunakan oleh manajer maupun non-manajer dalam perusahaan untuk membuat keputusan dalam memecahkan masalah [5].

\subsection{Basis Data}

Basis data adalah sumber data yang digunakan secara bersama oleh seluruh pengguna dalam organisasi. Setiap pengguna yang berasal dari fungsi yang berbeda dalam suatu organisasi akan membutuhkan data yang berbeda untuk diguanakan dalam mengerjakan tugasnya sehari-hari [6].

\subsection{Entity Relationship Diagram (ERD)}

Entity Relationship Diagram (ERD) adalah sekumpulan cara atau peralatan untuk mendeskripsikan data-data atau objek-objek yang dibuat berdasarkan dan berasal dari dunia nyata yang disebut entitas (entity) serta hubungan (relationship) antar entitas-entitas tersebut dengan menggunakan beberapa notasi [7].

\subsection{Class Diagram}

Class adalah sebuah spesifikasi yang jika diinstansiasi akan menghasilkan sebuah objek dan merupakan inti dari pengembangan dan desain berorientasi objek. Class menggambarkan keadaan (atribut/properti) suatu sistem, sekaligus menawarkan layanan untuk memanipulasi keadaan tersebut (metoda/fungsi) [8]. Diagram kelas atau class diagram menggambarkan struktur sistem dari segini pendefinisian kelas-kelas yang akan dibuat untuk membangun sistem [9].

\subsection{Use Case Diagram}

Use case atau diagram use case merupakan pemodelan untuk kelakuan (behavior) sistem informasi yang akan dibuat [9]. Use case diagram menggambarkan fungsionalitas yang diharapkan dari sebuah sistem. Sebuah use case merepresentasikan sebuah interaksi antara aktor dengan sistem [8]. 


\subsection{Activity Diagram}

Diagram aktivitas atau activity diagram menggambarkan workflow (aliran kerja) atau aktivitas dari sebuah sistem atau proses bisnis atau menu yang ada pada perangkat lunak [9]. Activity diagrams menggambarkan berbagai alir aktivitas dalam sistem yang sedang dirancang, bagaimana masing-masing alir berawal, decision yang mungkin terjadi, dan bagaimana mereka berakhir [8].

\subsection{Sequence Diagram}

Sequence diagram menggambarkan interaksi antar objek di dalam dan disekitar sistem, termasuk pengguna, display, dan sebagainya berupa message yang digambarkan terhadap waktu [9]. Sequence diagram terdiri antar dimensi vertikal (waktu) dan dimensi horizontal (objek-objek yang terkait) [8].

\subsection{Framework Laravel}

Laravel adalah sebuah framework PHP yang dirilis dibawah lisensi MIT, dibangun dengan konsep MVC (Model View Controller). Laravel adalah pengembangan website berbasis MVC yang ditulis dalam PHP yang dirancang untuk meningkatkan kualitas perangkat lunak dengan mengurangi biaya pengembangan awal dan biaya pemeliharaan, dan untuk meningkatkan pengalaman bekerja dengan aplikasi dengan menyediakan sintaks yang ekspresif, jelas dan menghemat waktu. MVC adalah teknik atau konsep yang memisahkan komponen utama menjadi tiga komponen yaitu Model, View dan Controller [10].

\section{Metode Pengabdian Masyarakat}

\subsection{Metode Pelaksanaan Kegiatan}

Metode pelaksanaan kegiatan atau langkah-langkah yang akan dilakukan dalam kegiatan pengabdian kepada masyarakat ini diperlihatkan pada gambar berikut.

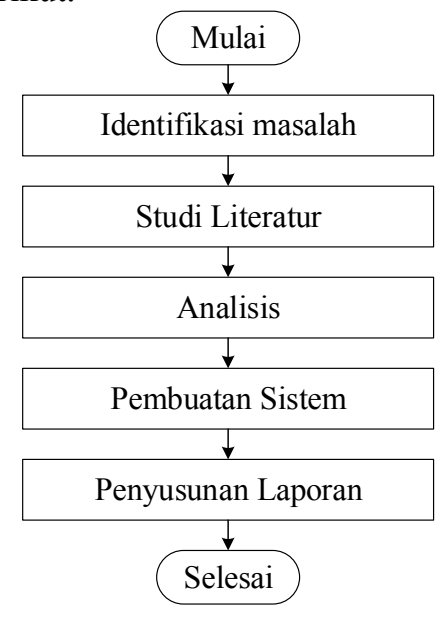

Gambar 1. Diagram alir pelaksanaan kegiatan

Pelaksanaan kegiatan dilakukan dengan identifikasi masalah pada Program Studi Teknik Informatika yang akan digunakan untuk membangun sistem informasi manajemen ruangan. Dalam mengidentifikasi masalah, digunakan metode wawancara dan diskusi untuk mendapatkan informasi mengenai sistem yang ada dan kebutuhan sistem yang diharapkan pengguna. Untuk menunjang kegiatan, dilakukan studi literatur sebagai referensi dalam membangun sistem informasi agar dapat menyelesaikan permasalahan yang teridentifikasi dan memilih bahasa pemrograman yang tepat untuk membuat sistem informasi berbasis website yang sesuai dengan kebutuhan. Kemudian informasi yang telah diperoleh, dianalisis untuk mendapatkan data yang diperlukan sistem yang akan dibuat untuk mengatasi permasalahan instansi terkait yaitu Program Studi Teknik Informatika.

\subsection{Waktu Kegiatan}

Perencanaan waktu kegiatan adalah selama tiga bulan termasuk waktu untuk persiapan. Persiapan yang perlu dilakukan sebelum kegiatan pengabdian kepada masyarakat antara lain :

1. Melakukan indentifikasi masalah terkait kebutuhan sistem dengan metode wawancara kepada pegawai Program Studi Teknik Informatika. 
2. Menetapkan hari, tanggal kegiatan, tempat serta peralatan yang perlu dipersiapkan untuk pelaksanaan kegiatan.

3. Merancang dan mendesain sistem informasi manajemen ruangan.

4. Menerapkan bahasa pemrograman untuk membuat sistem informasi manajemen ruangan berbasis website.

5. Mempersiapkan bahan untuk demonstrasi sistem yang telah dirancang dan dibuat.

6. Melakukan uji coba pada sistem yang telah dibuat dan memberikan pelatihan kepada pegawai Program Studi Teknik Informatika.

7. Melakukan evaluasi sistem dalam bentuk kuesioner kepada mahasiswa sebagai responden.

\subsection{Peserta Kegiatan}

Peserta kegiatan dari pelatihan sistem informasi manajemen ruangan Program Studi Teknik Informatika adalah pegawai yang bertugas mengatur administrasi ruangan pada Program Studi Teknik Informatika.

\subsection{Perancangan Sistem}

Pengembangan perangkat lunak dilakukan menggunakan kaidah software engineering (rekayasa perangkat lunak). Dalam teori software engineering terdapat beberapa macam model proses pengembangan perangkat lunak. Dalam hal ini digunakan model waterfall untuk pembangunan sistem. Model waterfall atau yang sering disebut model classic life cycle menunjukkan pengembangan perangkat lunak secara berurutan dan sistematis dimulai dari tahap analisis kebutuhan sistem, desain, coding, testing/verification, dan maintenance.

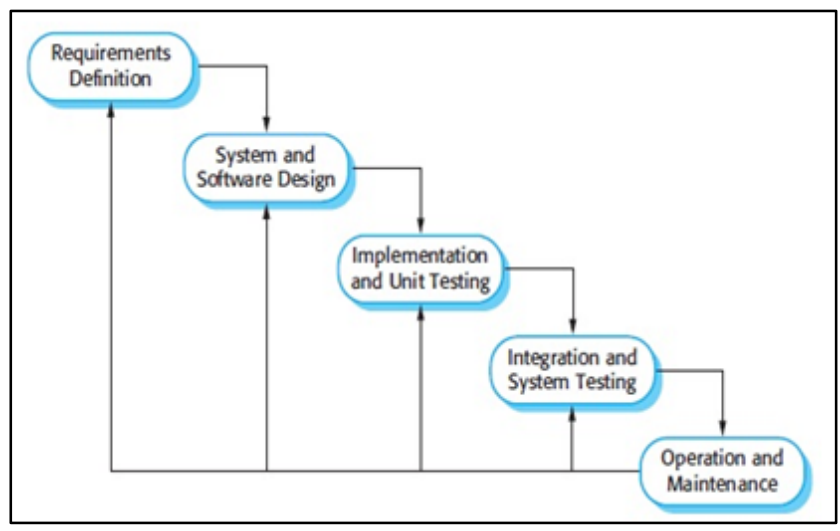

Gambar 2. Model waterfall[11]

\subsection{Analisis Sistem}

Pada analisis sistem ini dilakukan analisis dan pembuatan terhadap use case diagram sistem. Adapun Use Case Diagram dari Sistem Informasi Manajemen Ruangan sebagai berikut.

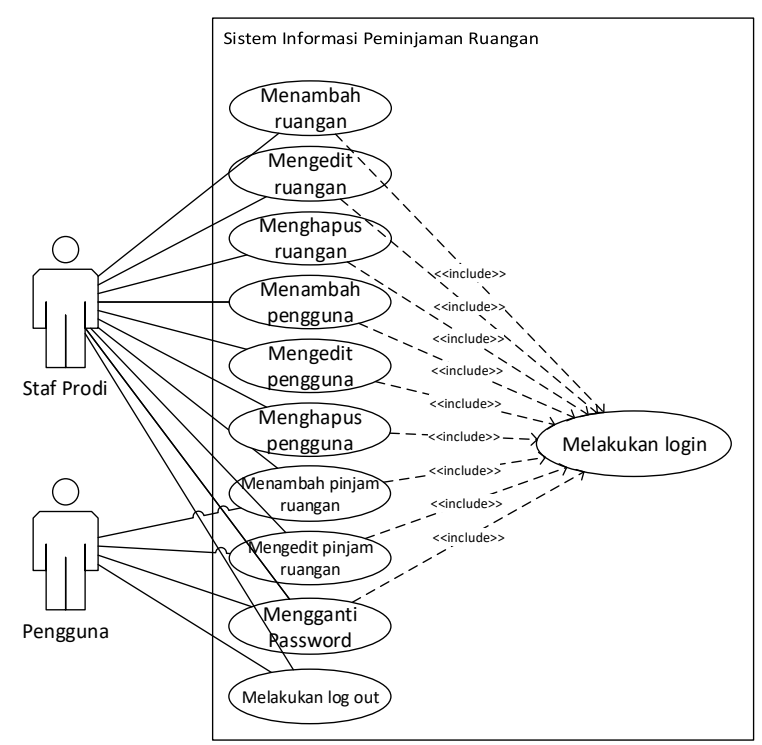

Gambar 3. Use case diagram 
Terdapat dua aktor pada sistem ini yaitu Staf Prodi dan pengguna. Adapun proses yang dapat dilakukan Staf Prodi pada sistem diantaranya yaitu melihat menambah ruangan, mengedit ruangan, menghapus ruangan, menambah pengguna, mengedit pengguna, menghapus pengguna, menambah pinjam ruangan, mengedit pinjam ruangan, mengganti password, dan melakukan log out. Sedangkan pengguna dapat menambah pinjam ruangan, mengedit pinjam ruangan, mengganti password, dan melakukan log out. Masing-masing proses tersebut harus melalui proses login terlebih dahulu untuk dapat dilakukan, sehingga proses-proses include ke proses login.

\subsection{Desain Sistem}

Pada sistem infomrasi peminjaman ruangan berbasis web ini terdapat dua diagram yaitu Entity Relationship Diagram berikut penjelasannya:

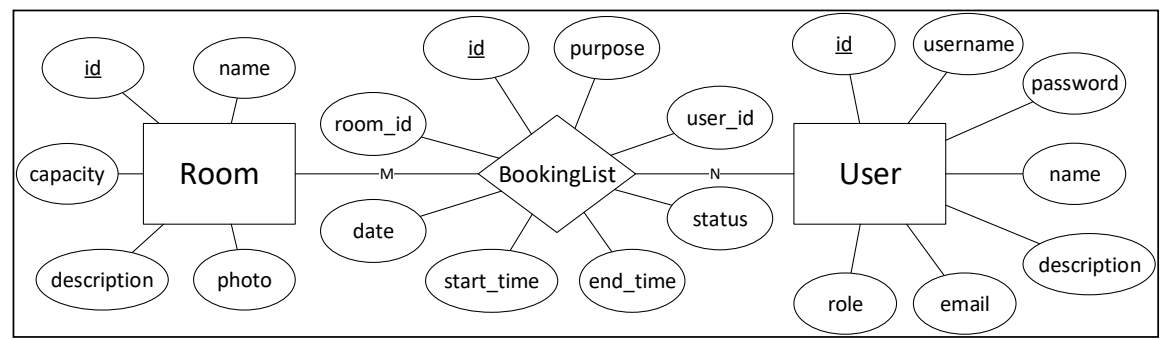

Gambar 4. ERD sistem informasi peminjaman ruangan

Terdapat tiga entitas pada ERD yaitu entitas Room, dan User serta BookingList sebagai penghubung. Entitas Room memiliki beberapa atribut $i d$, name, description, capacity dan photo. Entitas BookingList memiliki atribut $i d$, date, end_time, start_time, status, purpose, user_id yang merupakan foreign key dari Entitas User dan room_id yang merupakan foreign key dari Entitas Room. Entitas User memiliki beberapa atribut id, username, password, name, description, email, dan role. Entitas Room memiliki hubungan 1-M ke BookingList yang berarti bahwa sebuah room_id yang merupakan foreign key Entitas Room bisa berada pada beberapa baris data BookingList. Begitu pula User memiliki hubungan 1-N ke BookingList yang berarti bahwa sebuah user_id yang merupakan foreign key Entitas User bisa berada pada beberapa baris data BookingList. Jadi berdasarkan ERD di atas, satu user dapat membooking beberapa ruangan yang sama untuk waktu yang berbeda.

\section{Hasil dan Pembahasan}

Identifikasi masalah pada instansi dilakukan untuk menganalisis sistem yang telah berjalan dan untuk mengetahui kebutuhan yang diperlukan. Kegiatan wawancara pegawai yang terlibat pada sistem yang berjalan juga dilakukan untuk mengetahui permasalaham secara detail. Hasil identifikasi masalah yang dideteksi yaitu pada sistem yang berjalaan saat ini, masih berjalan dengan manual, dalam arti, pendataan terhadap ruangan dilakukan secara manual. Terjadi pula human error yaitu kealpaan pegawai prodi pada saat kegiatan untuk hari tersebut. Maka dibutuhkan sistem yang memudahkan pegawai untuk mengingat data pada hari tersebut. Kemudian melakukan desain terhadap hasil analisis sesaui dengan kaidah Rekayasa Perangkat Lunak. Dilakukan juga studi literatur sebagai pembanding untuk mengetasi permasalahan yang ada dan penggunaan bahasa pemrograman PHP dan Framework Laravel dalam pembuatan sistem. Selanjutnya implementasi dilakukan dengan melakukan coding.

Sistem informasi manajemen ruangan digunakan untuk meningkatkan efisiensi pekerjaan pada birokrasi di program studi Teknik informatika, berikut merupakan implementasi dan fitur-fitur untuk meminimalisir kesalahan dan meningkatkan pelayanan prodi.

a. Login

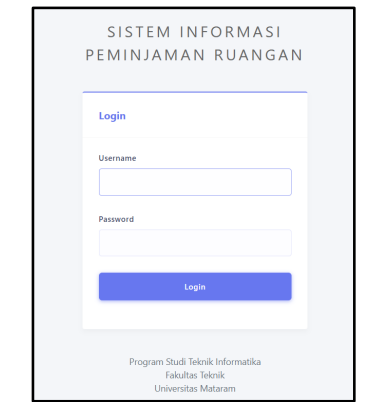

Gambar 5. Halaman log in 
Halaman ini adalah halaman pertama yang akan ditampilkan pada sistem, pengguna perlu log in untuk dapat menggunakan fitur-fitur yang ada di dalamnya, fitur ini juga sebagai fitur kemanan paling standar pada sistem pada umumnya. Pengguna perlu memasukkan username dan password untuk bisa masuk ke dalam sistem.

b. Dashboard

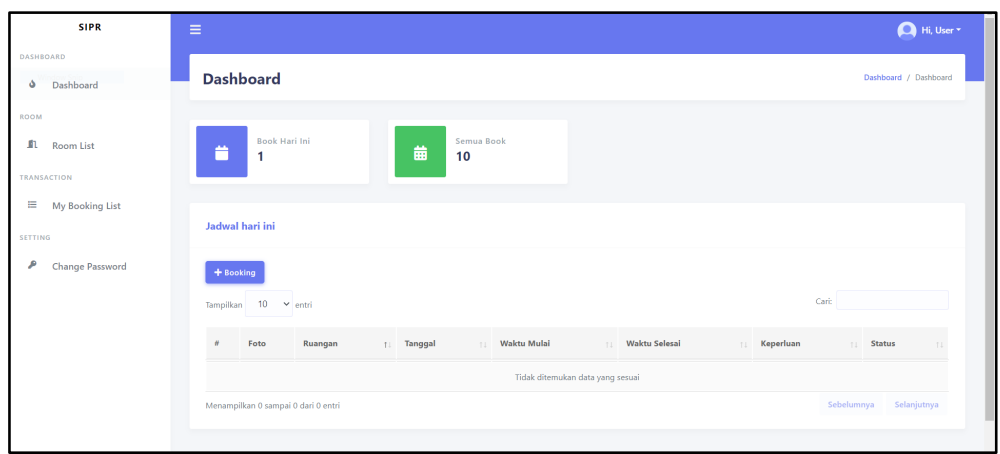

Gambar 6. Halaman dashboard

Halaman ini merupakan halaman pertama yang akan tampil setelah login, terdapat daftar jadwal ruangan yang dipinjam untuk digunakan pada "hari ini". Pada tabel terdapat nama ruangan dan jadwal (tanggal, waktu mulai dan waktu selesai ruangan yang dipinjam). Terdapat pula fitur tombol booking untuk mereservasi ruangan yang ingin digunakan di masa datang.

c. Room

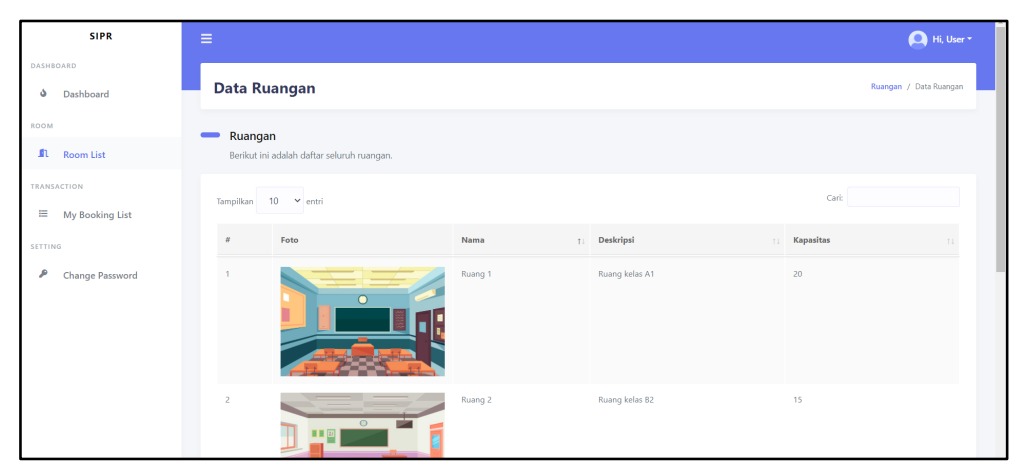

Gambar 7. Halaman Room List

Halaman ini digunakan untuk melihat daftar seluruh ruangan pada prodi yang datanya telah dimasukkan oleh admin.

d. User

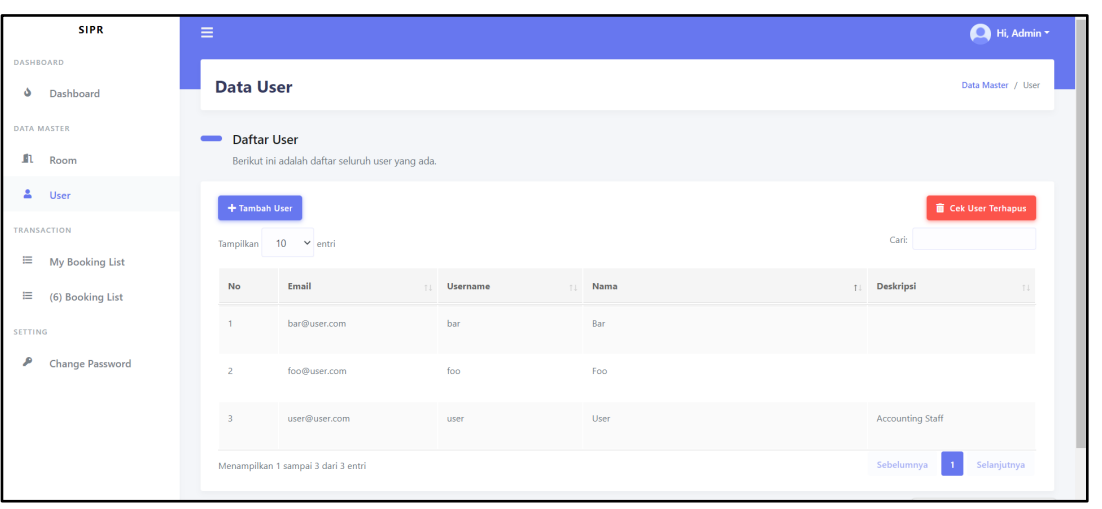

Gambar 8. Halaman User List

Halaman ini hanya bisa dilihat oleh Admin, bagi pengguna biasa fitur ini tidak ditampilkan. Terdapat daftar user yang telah ter-register pada sistem. Admin dapat menambah user baru maupun menghapusnya. Begitu pula admin juga dapat mengganti password user bila user lupa terhadap password lamanya sebagai antisipasi bila hal tersebut terjadi. 
e. My Booking List

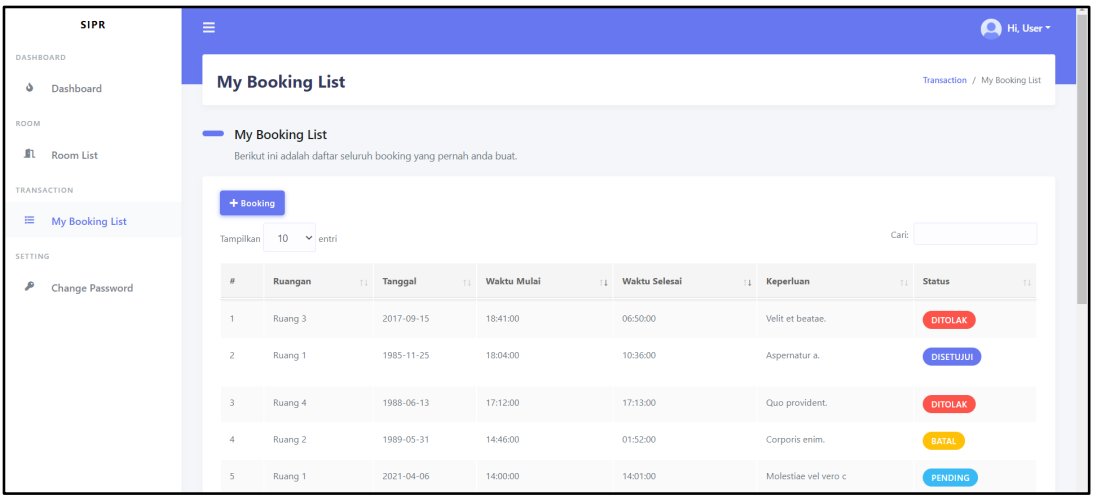

Gambar 9. Halaman my booking list

Halaman ini merupakan halaman seluruh daftar ruangan yang pernah di reservasi oleh user. User juga dapat memiliki opsi untuk membatalkan rservasi ruangan dengan klik pada opsi "batalkan" di bawah nama ruangan dengan mengarahkan kursor ke nama ruangan.

f. Booking List

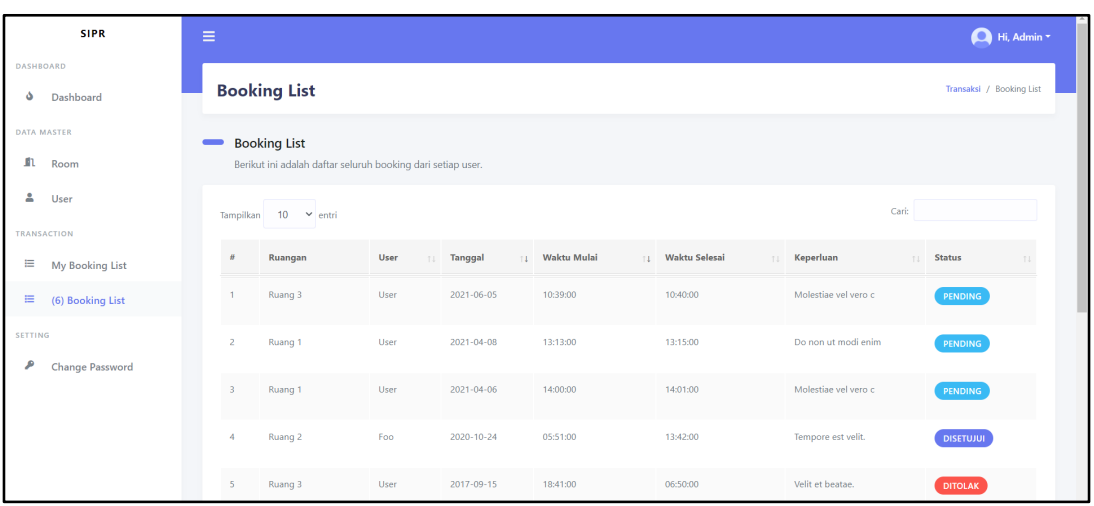

Gambar 10. Halaman booking list

Halaman ini hanya bisa dilihat oleh admin, terdapat daftar seluruh ruangan yang pernah direservasi oleh semua $u$ ser. Bagi admin juga dapat mengizinkan ruangan-ruangan yang dapat digunakan, dengan mengarahkan kursor pada nama ruangan akan terdapat opsi "setujui" atau "tolak". Admin juga dapat mereservasi ruangan namun pada sistem akan otomatis menyetujui reservasi admin.

g. Change Password

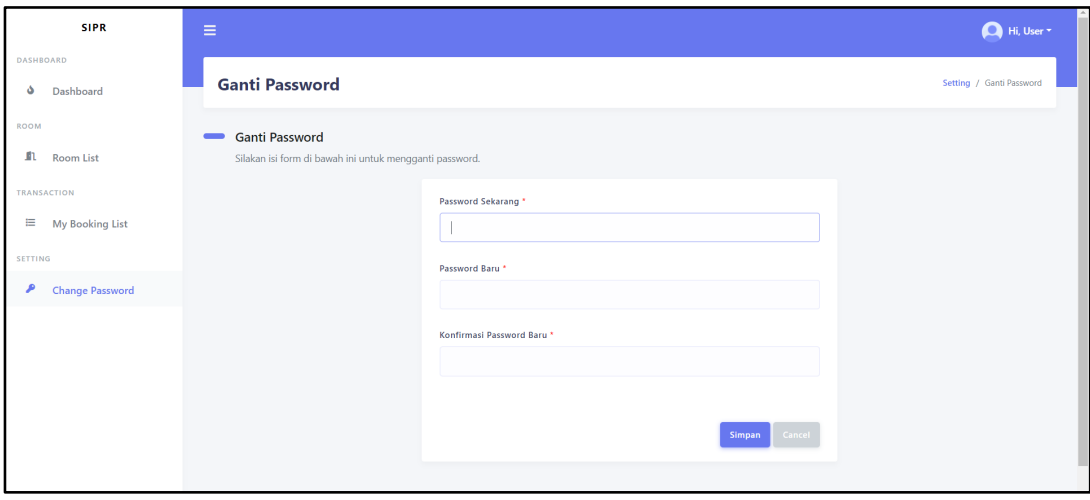

Gambar 11. Halaman Change Password

Halaman ini digunakan untuk mengganti password user, baik admin maupun pengguna biasa. Dengan memasukkan password lama dan memasukkan password baru. Fitur ini berbeda dengan fitur "ganti password" pada halaman user yang dimiliki admin yang hanya akan me-reset password user. Fitur ini digunakan untuk memperbarui password. 
Fitur-fitur pada sistem informasi ini berfokus pada admin, dapat terlihat pada fitur-fitur yang tersedia lebih terfokus pada admin. Pengguna biasa di sini dapat sebagai opsional. Hal ini dikarenakan pengguna bisa dari sisi dosen dan mahasiswa, perlu adanya sinkronisasi data yang dimiliki oleh perguruan tinggi, misalnya melalui Single Sign On yang telah diterapkan. Namun demikian, manfaatnya diharapkan tetap dirasakan karena tetap dapat membantu admin dalam memonitor ruangan-ruangan yang direservasi.

Pemahaman pegawai terhadap teknologi informasi memudahkan dalam penelasan kerja sistem kepada pegawai Pogram Studi Teknik Infomatika. Dengan pengetahuan dasar penggunaan komputer yang baik, pegawai dapat mudah adaptasi dengan penggunaan sistem yang dibuat dan juga memberikan kritik dan saran pada saat pengembangan sistem, sehingga sistem dapat membantu meningkatkan produktivitas kinerja pegawai.

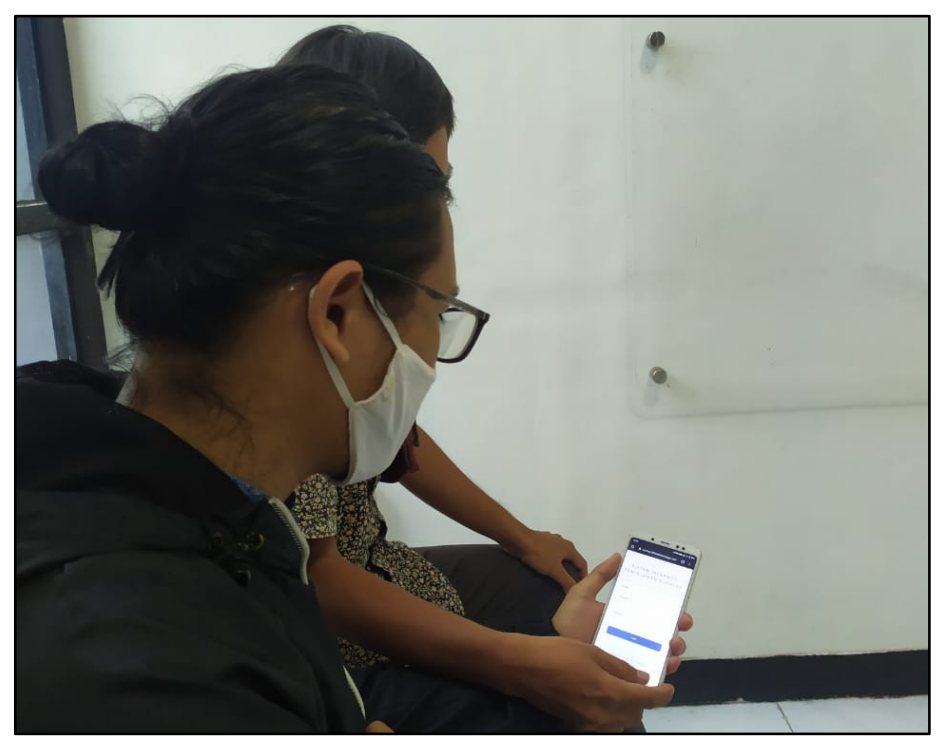

Gambar 12. Menampilkan sistem pada browser handphone

Selain pada browser kopmuter, sistem juga dapat diakses dengan menggunakan handphone yang membuat sistem menjadi lebih praktis untuk digunakan. Sistem dirancang agar dapat responsif terhadap ekosistem. Pada Gambar 11 sistem dapat diakses melalui browser dari handphone.

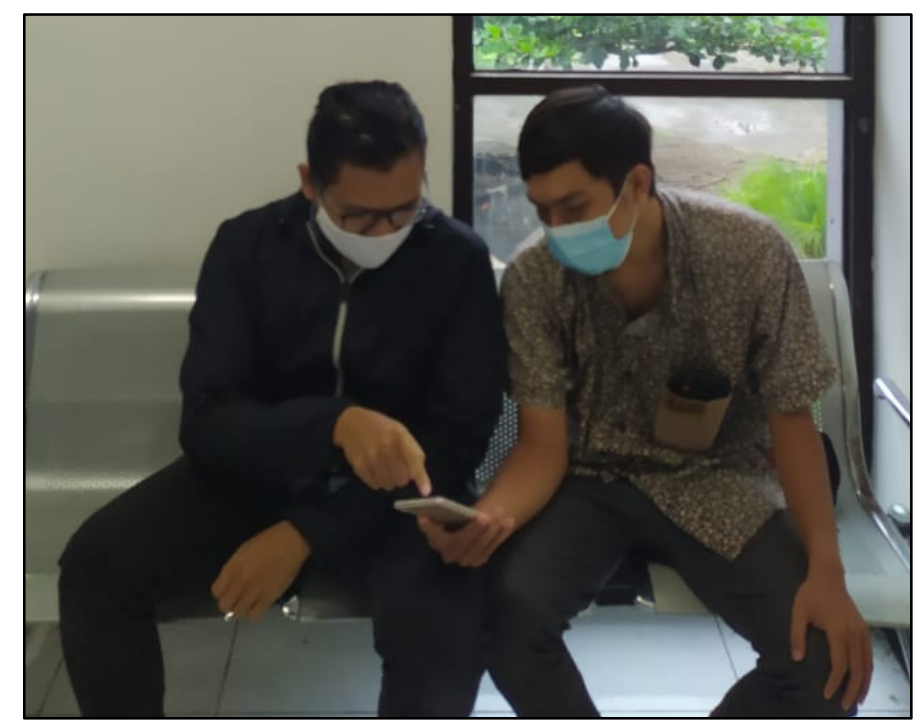

Gambar 13. Uji coba sistem kepada pegawai

Proses uji coba berjalan lancar dan tidak ada kendala berarti, dikarenakan pegawai sudah familiar dengan teknologi informasi dan terbiasa mengoperasikan komputer sehingga dapat cepat beradaptasi pada saat menggunakan sistem informasi yang dibuat pada kegiatan pengabdian masyarakat ini. 
Setelah implementasi sistem, diadakan pengujian pada sistem. Pengujian sistem ini menggunakan black box testing. Pengujian black box dilakukan dengan cara melakukan testing seluruh fitur yang ada dengan memasukkan data yang dibutuhkan pada sistem [12]. Hasilnya seluruh fitur yang diuji berhasil dijalankan dengan baik.

Tabel 1. Hasil Black Box Testing

\begin{tabular}{|c|c|c|c|}
\hline $\begin{array}{c}\text { Fitur yang } \\
\text { diuji }\end{array}$ & Input & Hasil yang diharapkan & Hasil pengujian \\
\hline Login & $\begin{array}{l}\text { Username dan } \\
\text { password }\end{array}$ & $\begin{array}{l}\text { - Sistem tidak pengguna mengizinkan masuk ke } \\
\text { sistem jika username atau password salah } \\
\text { - Pengguna dapat masuk ke sistem jika username } \\
\text { dan password benar. }\end{array}$ & $\begin{array}{l}\text { Sesuai yang } \\
\text { diharapkan }\end{array}$ \\
\hline $\begin{array}{l}\text { Menambahkan } \\
\text { data ruangan }\end{array}$ & $\begin{array}{l}\text { Form nama, } \\
\text { deskripsi, } \\
\text { kapsasitas, dan foto. }\end{array}$ & $\begin{array}{l}\text { - Sistem akan memberikan informasi bahwa form } \\
\text { tidak boleh kosong pada yang bertanda bintang. } \\
\text { - Sistem akan memberikan informasi bahwa foto } \\
\text { harus berupa file gambar dan maksimal ukuran } \\
\text { sebesar } 2048 \mathrm{~kb} \text {. } \\
\text { - Sistem menyimpan data jika semua data sudah } \\
\text { sesuai. }\end{array}$ & $\begin{array}{l}\text { Sesuai yang } \\
\text { diharapkan }\end{array}$ \\
\hline $\begin{array}{l}\text { Menambahkan } \\
\text { data User }\end{array}$ & $\begin{array}{l}\text { Form email, } \\
\text { username, } \\
\text { password, confirm } \\
\text { password, nama, } \\
\text { dan deskripsi. }\end{array}$ & $\begin{array}{l}\text { - Sistem akan memberikan informasi bahwa form } \\
\text { tidak boleh kosong pada yang bertanda bintang. } \\
\text { - Email harus sesuai format email. } \\
\text { - Password dan confirm password harus sama } \\
\text { - Sistem menyimpan data jika semua data sudah } \\
\text { sesuai. }\end{array}$ & $\begin{array}{l}\text { Sesuai yang } \\
\text { diharapkan }\end{array}$ \\
\hline $\begin{array}{l}\text { Menambahkan } \\
\text { data booking } \\
\text { ruangan }\end{array}$ & $\begin{array}{lr}\text { Form } & \text { nama } \\
\text { ruangan, } & \text { tanggal } \\
\text { booking, } & \text { waktu } \\
\text { mulai, } & \text { waktu } \\
\text { selesai, } & \text { dan } \\
\text { keperluan. } & \end{array}$ & $\begin{array}{l}\text { - Sistem akan memberikan informasi bahwa form } \\
\text { tidak boleh kosong pada yang bertanda bintang. } \\
\text { - Sistem akan memberikan informasi bahwa } \\
\text { tanggal booking berisi tanggal hari ini atau } \\
\text { setelah tanggal hari ini } \\
\text { - Sistem akan memberikan informasi bahwa waktu } \\
\text { mulai harus berisi waktu setelah waktu saat ini. } \\
\text { - Sistem akan memberikan informasi bahwa waktu } \\
\text { selesai harus berisi waktu setelah waktu mulai. } \\
\text { - Sistem menyimpan data jika semua data sudah } \\
\text { sesuai. }\end{array}$ & $\begin{array}{l}\text { Sesuai yang } \\
\text { diharapkan }\end{array}$ \\
\hline $\begin{array}{l}\text { Mengganti } \\
\text { password }\end{array}$ & $\begin{array}{l}\text { Form password } \\
\text { sekarang, password } \\
\text { baru, dan } \\
\text { konfirmasi } \\
\text { password baru. }\end{array}$ & $\begin{array}{l}\text { - Sistem akan memberikan informasi bahwa form } \\
\text { tidak boleh kosong pada yang bertanda bintang. } \\
\text { - Sistem akan memberikan informasi bahwa harus } \\
\text { sesuai password yang ada. } \\
\text { - Sistem akan memberikan informasi bahwa } \\
\text { password baru dan konfirmasi password baru } \\
\text { harus sama. } \\
\text { - Sistem menyimpan data jika semua data sudah } \\
\text { sesuai. }\end{array}$ & $\begin{array}{l}\text { Sesuai yang } \\
\text { diharapkan }\end{array}$ \\
\hline
\end{tabular}

Pengujian sistem selanjutnya dilakukan dengan menjawab kuesioner yang diberikan. Parameter pengujian yang digunakan pada metode ini adalah pertanyaan pada Tabel 2. Dari pertanyaan tersebut, responden diminta untuk menjawab dengan mencentang jawaban sesuai dengan ketentuan Mean Opinion Scores sebagai berikut :

1. Sangat Setuju : Berbobot 5

2. Setuju : Berbobot 4

3. Cukup : Berbobot 3

4. Tidak Setuju : Berbobot 2

5. Sangat Tidak Setuju : Berbobot 1

Data diolah dengan cara mengalikan setiap poin jawaban dengan bobot yang sudah ditentukan. Dari hasil perhitungan dalam mengalikan setiap bobot jawaban, maka didapatkan hasil nilai jumlah bobot untuk dicari nilai 
rata-rata jawaban dengan membagi jumlah bobot dengan jumlah responden. Setelah didapatkan nilai rata-rata, kemudian menentukan persentase hasil uji dengan membagi nilai rata-rata jawaban dengan banyaknya pilihan

Berikut hasil pengujian berupa daftar pertanyaan dan hasil perhitungan bobot jawaban dari quisioner yang dilakukan pada masing masing responden yang berjumlah 5 orang yang merupakan mahasiswa Program Studi Teknik Informatika Universitas Mataram.

Tabel 2. Hasil kuesioner

\begin{tabular}{|c|c|c|c|c|c|c|c|}
\hline \multirow[b]{2}{*}{ No } & \multirow[b]{2}{*}{ Pertanyaan } & \multicolumn{5}{|c|}{ Bobot } & \multirow[b]{2}{*}{ Mean } \\
\hline & & $\begin{array}{l}\text { Sangat } \\
\text { Setuju }\end{array}$ & Setuju & Cukup & $\begin{array}{l}\text { Tidak } \\
\text { Setuju }\end{array}$ & $\begin{array}{c}\text { Sangat } \\
\text { Tidak } \\
\text { Setuju }\end{array}$ & \\
\hline 1 & $\begin{array}{l}\text { Apakah sistem sudah bekerja sesuai dengan } \\
\text { kegunaan dan fungsinya? }\end{array}$ & 0 & 3 & 2 & 0 & 0 & 72 \\
\hline 2 & $\begin{array}{l}\text { Dalam hal desain, apakah sistem mudah untuk } \\
\text { dibaca dan dipahami? }\end{array}$ & 0 & 2 & 2 & 1 & 0 & 64 \\
\hline 3 & $\begin{array}{l}\text { Apakah sistem menghasilkan informasi yang } \\
\text { detail? }\end{array}$ & 0 & 3 & 1 & 1 & 0 & 68 \\
\hline 4 & $\begin{array}{l}\text { Apakah sistem yang dibuat sudah sesuai } \\
\text { dengan kebutuhan? }\end{array}$ & 0 & 3 & 2 & 0 & 0 & 72 \\
\hline 5 & $\begin{array}{l}\text { Apakah sistem yang dibuat mempermudah } \\
\text { pekerjaan? }\end{array}$ & 0 & 3 & 2 & 0 & 0 & 72 \\
\hline \multicolumn{7}{|c|}{ Mean Opinion Score } & 69.6 \\
\hline
\end{tabular}

Berdasarkan hasil pengujian MOS yang dilakukan oleh 5 orang responden, pengujian menghasilkan nilai MOS 69.6 dari interval 100 dengan mengonversikan nilai MOS ke dalam Absolute Category Rating (ACR) yang memiliki lime level skala, yaitu Sempurna bernilai 5, Baik bernilai 4-4.9, Cukup bernilai 3-3.9, buruk bernilai 2-2.9 dan sangat buruk bernilai 1-1.9[13]. Maka setelah dikonversikan nilainya menjadi 3.48, menunjukkan bahwa Sistem Informasi Manajemen Ruangan Teknik Informatika berjalan dengan cukup baik. Hal ini dapat terjadi karena saat pengisian kuesioner, responden tidak mendapat petunjuk cara menggunakan fitur-fitur yang ada pada sistem terutama mengenai informasi yang terdapat pada sistem. Dibuktikan dengan adanya jawaban "Tidak Setuju” pada pertanyaan dua dan tiga. Sehingga perlu adanya pelatihan ataupun dokumentasi cara penggunaan (tutorial) sistem.

\section{KESIMPULAN DAN SARAN}

Berdasarkan hasil pengamatan dari kegiatan pengabdian kepada masyarakat yang telah dilakukan, dapat disimpulkan bahwa sistem informasi manajemen ruangan dapat dibuat untuk memenuhi kebutuhan Program Studi Teknik Informatika berdasarkan dari hasil analisa terhadap kebutuhan serta kinerja dari instansi tersebut. Kegiatan manajemen ruangan pada Program Studi Teknik informatika dapat dilakukan pada sistem manajemen ruangan berbasis website ini hasil dari proses pelatihan kepada pegawai yang berjalan dengan baik karena telah mampu mengoperasikan sistem. Fitur yang terdapat pada sistem dapat berjalan dengan baik sesuai yang diharapkan berdasarkan hasil uji black box dan mendapat Mean Opinion Scores sebesar 69.6.

Untuk memaksimalkan hasil kegiatan pengabdian kepada masyarakat, diberikan saran agar sistem ini dapat lebih baik, yaitu dengan menyingkronisasi sistem ini dengan Single Sign On Universiyas Mataram untuk mempermudah manajemen user, menambahkan fitur notifikasi ke pengguna, dan melakukan pelatihan kepada pengguna (dosen dan mahasiswa) serta memberikan dokumentasi cara penggunaan (tutorial) website.

\section{DAFTAR PUSTAKa}

[1] S. Aswati, N. Mulyani, Y. Siagian, and A. Z. Syah, "Peranan Sistem Informasi Dalam Perguruan Tinggi," J. Teknol. dan Sist. Inf., vol. 1, no. 2, pp. 79-86, 2015, [Online]. Available: http://is.its.ac.id/pubs/oajis/index.php/file/download_file/1466.

[2] D. M. Khairina, S. Maharani, and H. R. Hatta, "Sistem Informasi Manajemen Ruang (Simeru) Kelas (Studi Kasus: FKTI Universitas Mulawarman),” Inform. Mulawarman J. Ilm. Ilmu Komput., vol. 13, no. 1, p. 30, 2018, doi: 10.30872/jim.v13i1.1023.

[3] M. Nugraha and Y. Nugraha, "Selamat Tinggal Bentrok! Efisiensi Pengelolaan Jadwal Kuliah dengan SIM- DRaW ( Sistem Informasi Manajemen Dosen , Ruang, dan Waktu ) Abstrak," Fountanins Infomatics J. Unida Gontor, vol. 3, no. 1, 2018. 
[4] J. Hartono, Analisis dan Desain Sistem Informasi. Yogyakarta: Andi Offset, 2005.

[5] J. McLeod, Sistem Informasi Manajemen, 7th ed. Jakarta: PT. Prehallindo, 2005.

[6] Fathansyah, Basis Data, 2nd ed. Bandung: Informatika Bandung, 2015.

[7] D. Edi and S. Betshani, "Analisis Data dengan Menggunakan ERD dan Model Konseptual Data Warehouse," J. Inform., vol. 5, no. 1, pp. 71-85, 2012.

[8] S. Dharwiyanti and R. S. Wahono, "Pengantar Unified Modeling LAnguage (UML)," IlmuKomputer.com, pp. 1-13, 2003, [Online]. Available: http://www.unej.ac.id/pdf/yanti-uml.pdf.

[9] M. Syarif and W. Nugraha, "Pemodelan Diagram UML Sistem Pembayaran Tunai Pada Transaksi ECommerce," J. Tek. Inform. Kaputama, vol. 4, no. 1, p. 70 halaman, 2020, [Online]. Available: http://jurnal.kaputama.ac.id/index.php/JTIK/article/view/240.

[10] M. K. Rahman, A. Aranta, and R. B. F. I. Sidharta, "Sistem Informasi Gofoodies Lombok Berbasis Website Menggunakan Framework Laravel dan Bootstrap,” J. Begawe Teknol. Inf., vol. 2, no. 1, pp. 8594, 2021, doi: 10.29303/jbegati.v2i1.418.

[11] I. Sommerville, Software Engineering (9th ed.; Boston, Ed.). Massachusetts: Pearson Education. 2011.

[12] N. Wafiya, N. Agitha, and Muliadi, "Perancangan Dan Pembuatan Sistem Informasi Perpustakaan Pada SDN 26 Mataram," J. Begawe Teknol. Inf., vol. 2, no. 1, pp. 46-53, 2021, doi: 10.29303/jbegati.v2i1.183.

[13] B. Naderi and S. Moller, "Transformation of Mean Opinion Scores to Avoid Misleading of Ranked Based Statistical Techniques," 2020 12th Int. Conf. Qual. Multimed. Exp. QoMEX 2020, pp. 23-26, 2020, doi: 10.1109/QoMEX48832.2020.9123078. 